\title{
A sales process framework to regain B2B customers
}

\author{
Annie Liu \\ Department of Marketing, Texas State University, San Marcos, Texas, USA \\ Mark Leach \\ Department of Marketing and Business Law, Loyola Marymount University, Los Angeles, California, USA, and \\ Richa Chugh \\ School of Marketing and International Business, Victoria University of Wellington, Wellington, New Zealand
}

\begin{abstract}
Purpose - The purpose of this study is to develop a sales process framework to facilitate business-to-business (B2B) customer reacquisition. A comprehensive CRM process needs to include reacquisition strategies. Yet, very few firms have formal procedures to guide reacquisition efforts. This gap in the sales process reflects the relatively sparse literature on B2B customer reacquisition models. The present research intends to fill this gap and creates a sales process model to guide salespeople to regain B2B lost customers.

Design/methodology/approach - Using critical incident technique (CIT), this study conducted in-depth interviews with 54 B2B salespeople. Each salesperson reported one successful and one unsuccessful reacquisition incidents. A total of 108 critical incidents were collected for analysis.

Findings - A four-step sales process model to regain B2B customers was developed and empirically supported, including: Segment lost customers; Assess reasons for loss; Develop reacquisition activities; and Implement reacquisition strategies.

Research limitations/implications - This study is qualitative and exploratory in nature; future research should develop dyadic surveys to validate the results.

Practical implications - This four-step reacquisition process allows sales firms to identify essential elements and establish protocols/policies to train and motivate salespeople. The framework can facilitate salespeople develop problem-focused solutions to correctly diagnose the situation and effectively re-negotiate with defected customers. Thus, this process may help reduce inefficiency in the reacquisition process and increase reacquisition ratios.

Social implications - By considering justice/fairness from customer's perspective, sales firm may properly recover lost business relationship, and do so in ways that are considered both just and ethical.

Originality/value - This is one of the first studies to examine the reacquisition of lost B2B customers. It expands on the traditional sales process to include four steps that enable a sales reacquisition process.
\end{abstract}

Keywords Attribution theory, B2B customer reacquisition, Justice theory, Lost customers, Sales process, Win back

Paper type Research paper

\section{Introduction}

Sales executives constantly search for opportunities to gain, retain and grow business opportunities for their firms. Yet no matter how effective a company's sales process or customer relationship management (CRM) program is, inevitably, some customers will defect and switch to other suppliers. Although there are well-established sales processes and frameworks to guide salespeople when acquiring new accounts and maintaining customer relationships, there are remarkably few studies or formal systems in place to guide customer reacquisition efforts. More research exploring reacquisition strategies and the development of proven frameworks is needed to provide

The current issue and full text archive of this journal is available on Emerald Insight at: www.emeraldinsight.com/0885-8624.htm

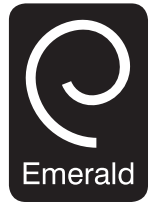

Journal of Business \& Industrial Marketing 30/8 (2015) 906-914

C Emerald Group Publishing Limited [ISSN 0885-8624]

[DOI 10.1108/JBIM-02-2014-0026] salespeople the tools to evaluate reacquisition opportunities and execute reacquisition strategies. Left without these frameworks and tools, salespeople may engage in reacquisition activities that are either ineffective or inefficient, or worse, they may participate in activities that run counter to the CRM goals of their sales firm.

The lack of attention paid to reacquisition in the academic literature is also troubling given the potential importance of customer reacquisition to a firm's implementation of a comprehensive sales process and a CRM program. By reacquiring lost customers with the right reacquisition strategy, sales executives can often facilitate the creation of higher-value transactions, form stronger bonds and redevelop highly profitable relationships with these buying firms. A well-designed reacquisition framework can also aid companies to better understand their market and competitive position.

The authors gratefully acknowledge funding support from the Sales Education Foundation and the Neil Rackham Research Award. Funding support did not include any role in the paper.

Received 1 February 2014

Revised 30 April 2014

Accepted 29 May 2014 
With the increasing levels of competition and customer demands, properly integrated reacquisition programs provide opportunities to improve companies' sales process and help guide their CRM efforts (Liu et al., 2012; Stauss and Friege, 1999). Strong reacquisition capabilities can become a source of competitive advantage.

Reacquiring "lost" customers differs from acquiring "new" customers in several key ways. For example, sales organizations can often leverage departed customers' transaction histories (Thomas et al., 2004) that are unavailable with new customers. Although customers' relationship portfolios will usually include information that can be leveraged, some of the past experiences and relationships may be deterrents to reacquisition. Accordingly, salespeople may need to counter strong negative attitudes or repair a relationship before any reacquisition initiatives can be successful. Furthermore, losing a customer to better pricing or value efforts requires a different reacquisition strategy than losing one after a service failure or other detrimental challenge to the pre-existing relationship. Most of all, reacquiring any lost customer often involves reactivating the customers' switching behavior. As customers' decisions to switch back typically require a reassessment of a supplier's relative value of the offering, as well as the relative value of past relationships, salespeople need to assess their windows of opportunity and persuade customers to "switch back" from the replacement supplier.

Contributing to the marketing and sales literature, this study intends to develop a business-to-business (B2B) sales process framework to facilitate the reacquisition of lost customers. We believe this research is one of the first to empirically investigate sales activities pertaining to reacquisition efforts in $\mathrm{B} 2 \mathrm{~B}$ sales organizations. The results of this paper will provide new insight and information to aid B2B sales executives to:

- systematically conduct customer defection analyses by identifying and segmenting types of lost customers and critically assess defection attributions; and

- design reacquisition efforts by selecting and implementing appropriate tactics and strategies.

\section{Literature review}

In $\mathrm{B} 2 \mathrm{~B}$ sales, both the buyers and sellers are engaged in a value co-creation process for economic exchange (Dixon et al., 2012). These exchange and sales processes are complex, dynamic and constantly evolving. As the marketplace becomes increasingly competitive and customers more value conscious, relationships and loyalty will likely be challenged. Changes in a customer's cost structure, personnel, purchasing motivations and goals, changes in the sales organization's personnel and processes and competitors' actions can strengthen or deteriorate an established relationship (Dwyer et al., 1987). As salespeople often manage customer loyalty in B2B relationships, salespeople play a vital role in reducing customer defection, regaining business, rebuilding value and repairing relationships (Palmatier et al., 2007; Johnson et al., 2001).

CRM literature consistently demonstrates the benefits of customer retention, including financial, attitudinal (e.g. brand preference and positive word of mouth [WOM]) and behavioral (e.g. repeat purchase and referral) (e.g. Reichheld,
1993; Page et al., 1996; Liu et al., 2005). Although the ultimate goal of CRM is to retain all profitable customers and expand their lifetime value, organizations realize a "perfect retention" record is impossible. In response, a body of research exploring the reacquisition of lost consumers has developed. Specifically, previous studies have examined competitive pricing, elapsed time, and second life-time value (SLTV) (Thomas et al., 2004); relative social capital and regret (Tokman et al., 2007; Liu et al., 2012); and attribution theory (Dalela, 2009), justice perceptions (Homburg et al., 2007) and the influence of cultural norms (Liu et al., 2012) to regain lost customers.

Recognizing the significant impact of customer defection on overall CRM goals, Stauss and Friege (1999) present a comprehensive customer management framework for categorizing prospective, existing and lost customers. They identify five types of lost customers (defectors) based on the prototype of the relationship dissolution, including the bought away, pulled away, unintentionally pushed away, moved away and intentionally pushed away customers (see details in the conceptual framework section). They stress the importance of identifying profitable customers through two-way communications and segmentation data.

Literature on service recovery has often applied attribution theory, equity theory (Adams, 1963) and justice theory (Tax et al., 1998) to examine antecedents to recovery and customer reactions (e.g. Hoffman and Kelley, 2000; Gonzalez et al., 2005). This literature has focused on customer attributions of service failure (e.g. Swanson and Kelley, 2001), failure typologies and recovery efforts (e.g. Johnston and Hewa, 1997; Gonzalez et al., 2010), recovery evaluations and strategies (e.g. Hoffman and Kelley, 2000), customer complaining behavior (e.g. Keaveney, 1995) and relationship selling and service recovery management (Gonzalez et al., $2005,2010)$. In general, justice theory and equity theory aim to compare the quality of both the process and content of the firm's recovery and retention efforts with the outcomes. Accordingly, justice theory can help evaluate the perceived procedural, interactive and distributive justice in the design and delivery of reacquisition strategies.

\section{Conceptual framework - a reacquisition sales process}

One of the oldest and most fundamental models within the sales discipline is the seven-step selling process (Moncrief and Marshall, 2005). Traditionally, this selling process consists of: prospecting, pre-approach, approach, presentation, overcoming objections, closing and follow-up activities (Dubinsky, 1980/1981). Given the rapidly changing sales environment, there have been numerous calls for modernizing and enhancing this process. For example, Marshall et al. (1999) identify new selling activates stemming from technology use. Moncrief and Marshall (2005) propose an updated selling process that takes into account a relationship selling approach centering on assessing and creating value while utilizing databases to facilitate the sales process. Plouffe et al. (2013) argue that refinement of the sales process is most needed in the later stages as competition becomes more formidable and selling cycles are elongated. They develop and test a model that incorporates negotiation practices into the 
sales process. Although these studies all enhance our understanding of what today's salespeople do to facilitate sales, they only examine a sales process that spans from prospecting, to customer acquisition, to account management. They do not examine lost customers and the process of reacquisition. Because reacquisition activities are likely very different from acquisition activities, a comprehensive sales process needs to include the examination of reacquiring lost customers (Stauss and Friege, 1999). To this end, we develop a framework of the reacquisition sales process.

Integrating consumer defection and service recovery literature (Stauss and Friege, 1999; Gonzalez et al., 2005) with our critical incident interview findings, we develop a reacquisition sales process framework (see Figure 1). This framework consists of two phases (i.e. the evaluation phase and the action phase), and four steps (i.e. segment defectors, assess responsibilities, develop reacquisition activities and implement reacquisition strategy). The two steps in the evaluation-focused phase require sales executives to conduct a customer defection analysis to gain insights of who the defectors are and why they left. The results of first two steps are then integrated into designing appropriate reacquisition efforts. The two steps in the action-oriented phase allow sales executives to map out what reacquisition strategy to undertake and how to implement activities to help ensure effective reacquisition efforts. These two phases and resulting four steps are briefly elaborated as below.
The evaluation phase - defection analysis

The main purpose of customer defection analysis is to help sales executives systematically evaluate the patterns of defected customers. By classifying defectors into one of the five typologies, sales executives can objectively deal with the lost customer by focusing on a defection prototype rather than the loss or setback. Furthermore, by first identifying the defection pattern, sales executives can more objectively assess customers' reasons for leaving. As not all defected customers are alike, this objective assessment of defectors will aid salespeople to assign priorities and design effective win-back strategies.

Step I: segment defectors based on reason for switching

Recognizing the significant impact of customer defections on overall CRM goals, Stauss and Friege (1999) developed a framework for analyzing lost consumers of services. They suggest first segmenting lost customers by the reason for their defection. Integrating Stauss and Friege's (1999) typology with findings from our critical incident interviews, we identify and compare five types of B2B lost customers as follows:

1 Bought away customers are often on the lookout for cheaper price. As a result, they are vulnerable to competitive pricing and seldom commit to a long-term relationship. As they can be easily lured away by competitor's lower price, bought away customers can also be bought back with competitive pricing. However, our findings suggest that the critical issue for the sales firm to

Figure 1 A sales process framework for B2B customer reacquisition efforts

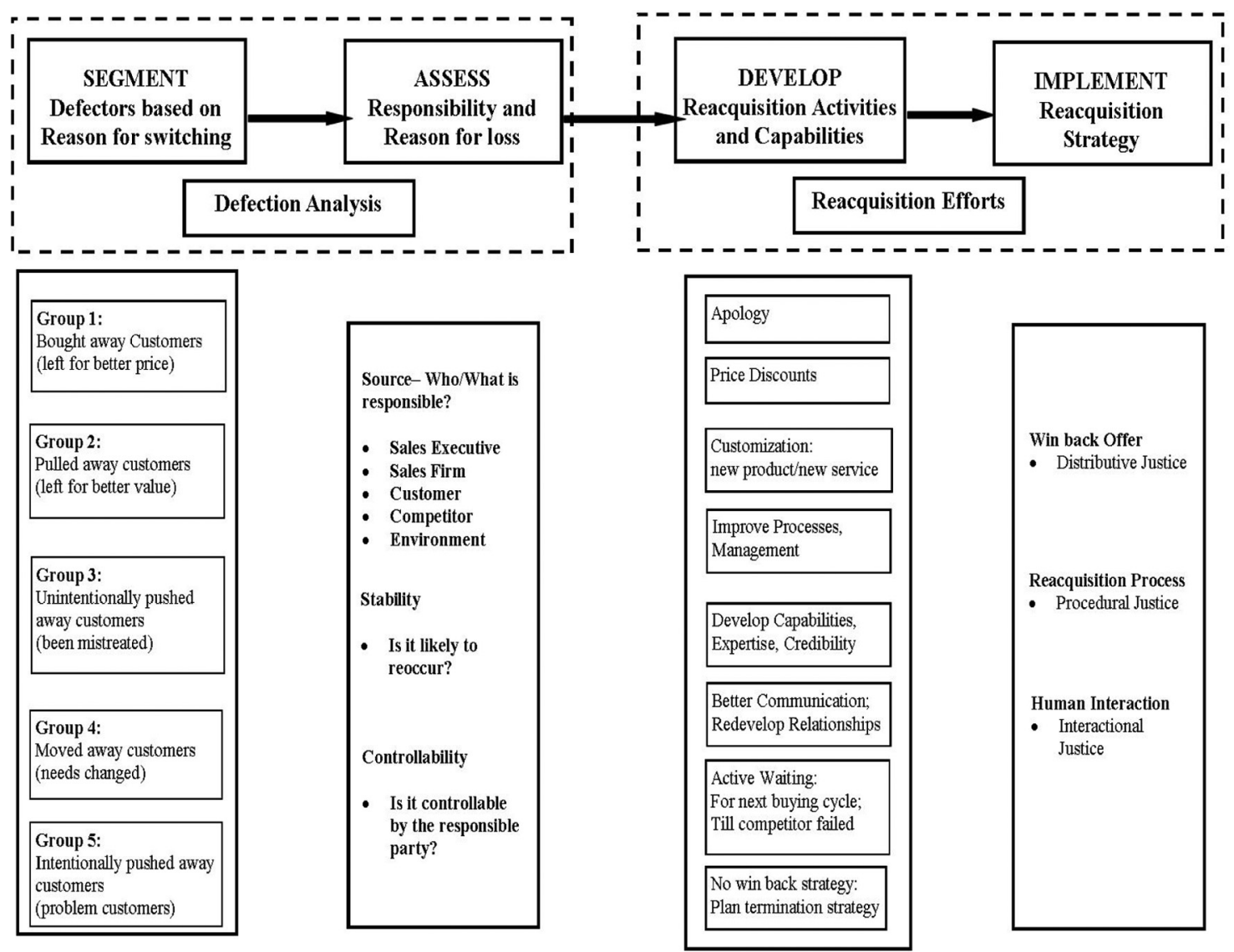


consider when regaining this type of customer is whether it will stay around long enough to be profitable, and if it is wise and worthwhile to play the "price war" game with competitors. As such, to successfully regain and retain this business, it may necessary for the sales firm to develop a program to lock in deal-prone customers.

2 Pulled away customers usually seek better value proposition from alternative suppliers and look for competitive offers with higher benefits and/or lower costs. They are strategy-driven and will closely collaborate with suppliers to co-create better value for the long run. Although they may seem demanding or particular, they are less deal-prone. Therefore, our findings reveal that the main issue to win-back pulled away customers is to co-develop value propositions that are unique and sustainable.

3 Unintentionally pushed away customers leave because of mistreatment or negligence. It is imperative that sales executives apologize for the mistakes to neutralize negative sentiments before making amends. Unintentionally pushed away customers often experienced service/product failures; therefore, service recovery and reacquisition may include compensation, reimbursement and discounts. However, findings from our in-depth interviews show that when customers experienced severe or repeated mistakes, a sales firm may need to wait for personnel changes in either or both the buying and sales center before win-back is possible.

4 Moved-away customers no longer need or see value in the product/service offerings. The moved-away customers may physically move to different markets that the company cannot serve, or they may move to some form of in-sourcing. Several sales executives noted that although this group of customers may seem lost for good, ending the relationship positively is important for referrals and WOM.

5 Intentionally pushed away customers are problematic or unprofitable customers, and the company no longer wants their business. Various salespeople commented that the art of dealing with this group of customers includes letting them fire themselves and leading them to competitors that may better match their needs. Again, positive relationship dissolution will help sales firms maintain positive brand image.

Step II: assess responsibility and reasons for loss

In addition to segmenting lost B2B customers by the five prototypes, it is critical to understand and evaluate the specifics of the situation that lead to the defection. As such, this second step in the defection analysis is attributional in nature - who/what is responsible? Will it happen again? And can it be prevented from reoccurring?

Although salespeople tend to make attributions of success primarily to internal factors (DeCarlo et al., 2007), in failure situations, salesperson attributions have been found to be related to both internal and external factors (Dixon et al., 2001; DeCarlo et al., 2007). Dixon et al. (2005) find that whether a salesperson intends to overcome failure by increasing effort, seeking assistance or changing strategies will depend on the attributions he or she makes. Attribution theory helps us understand how salespeople identify the causes associated with customer defection. This process involves sorting through various information cues and concludes in a judgment about whether the cause is something internal or external (Gilbert, 1995), reoccurring or non-reoccurring and controllable or uncontrollable (Weiner, 1980).

In this second step in the evaluation phase, analyzing causal inferences and interpretations of defection attribution can help sales executives better understand some of the hurdles they may face with customer reacquisition. Past literature suggests that salespeople make attributions about the causes and will work toward achieving a successful outcome (Dixon et al., 2001). A systematic attribution analysis will help sales executives gain insights into the reasons customers leave. Specifically, findings from our critical incident interviews show that the attribution analysis helps direct attentions to:

- Source: The responsible party may include an internal source (e.g. the sales executive and sales firm) or external source (e.g. customer, competitor or environment). When the source of customer defection is mainly attributed to the sales executive or firm, an internal evaluation needs to take place to correct mistakes.

- Stability: If the cause of defection is likely to reoccur (i.e. stable), then it is critical for sales executives to resolve the cause and learn from the situation.

- Controllable/Preventable: If the cause of customer defection is controllable or preventable, sales executives can look for predictive clues and take precautions against it happening again.

\section{The action phase - reacquisition efforts}

Taking into account the types and causes of the customer defection enables salespeople to develop and execute their reacquisition efforts. These efforts most likely require getting customers to reevaluate their previous decision to leave, reassess relative value among suppliers and switch back from a replacement supplier. With all this in mind, when planning their reacquisition strategy, salespeople must not only have a full understanding of what activities, capabilities, assets are available to them, but must also keep in mind the process by which these can be leveraged to facilitate positive reassessment by the customer. Therefore, this phase involves salespeople determining the appropriate reacquisition activities, and their potential effects on the prospective lost customer. We integrated justice theory's primary components - distributive, procedural and interactive justice - for measuring the overall fairness and effectiveness of the implementation of the reacquisition strategy (Tax et al., 1998).

\section{Step III: develop reacquisition activities and capabilities}

Depending on the types of service failures, service recovery literature suggests several effective recovery activities. This includes apology, price-related concessions (e.g. discounts, compensations and reimbursements) and no action (Gonzalez et al., 2005). In addition, our findings show that reacquisition process requires sales executives to re-approach and renegotiate with defected customers. As a result, this process facilitates co-creation with and customization for buyers. Past research shows that the customization process enables the development of more customer-oriented products/services, which results in greater customer satisfaction (Saxe and Weitz, 1982) and more favorable perceptions of service quality (Parasuraman et al., 1988). This type of customization process 
is also likely to evolve into boundary-open transactions allowing the buyer and seller to re-engage and share feelings with one another (Mars and Nicod, 1984). As a consequence, better communication, improved processes and/or new capabilities and expertise are developed and relationships are re-energized.

Additionally, several sales executives reveal the importance of "active waiting" - a strategic timing process by which to re-engage with customers even if they are not ready to switch back. The purpose of "active waiting" is to position the sales firm on the "consideration set" for the customer's next buying cycle. As important, "active waiting" may encourage a customer's return when the new supplier falls short on performance.

\section{Step IV: implement reacquisition strategy}

Justice theory is mainly concerned with perceived fairness of a response to a conflict situation, such as complaint handling and win-back activities. As noted, perceived justice comprises three components: procedural justice, interactive justice and distributive justice (Tax et al., 1998).

- Reacquisition process - incorporating procedural justice: Procedural justice focuses on the process that facilitates the final outcome (Greenberg, 1990). Therefore, to effectively implement reacquisition strategies, sales executives need to consider improving processes to approach defected customers, solicit solution-focused information from them, and develop capabilities and expertise to respond positively to the their needs.

- Salesperson behavior - considering interactional justice: Interactional justice involves using interpersonal skills in developing and delivering win-back offers and completing the reacquisition process (Tax et al., 1998). A sales executive's communication and relationship skills, attitude and willingness to resolve the situation (e.g. apology, listening, "active waiting") can contribute to positive interactional justice.

- Win-back offer - integrating distributive justice: Distributive justice focuses on the fairness of the outcome of the firm's reacquisition effort. As such, the sales firm's win-back offer may include price discounts and product/service customization (Hoffman and Kelley, 1996).

\section{Methodology}

The goal of this research is to develop a framework illustrating how sales executives attempt to reacquire lost customers. To gain in-depth knowledge of customer reacquisition, we conducted critical incident in-depth interviews. Critical incident technique (CIT) involves the use of specific stories and examples (i.e. incidents) that are content analyzed with the purpose of uncovering emergent themes, patterns and categories. As a qualitative methodology, CIT has been found to be particularly valuable at identifying categories and typologies (Bitner et al., 1990). Respondents for this study are B2B salespeople identified from a convenience sample developed from a major university's network in New Zealand. Therefore, our unit of analysis is a reacquisition incident. We pre-screened respondents to ensure that appropriate and knowledgeable individuals were selected to participate in the interviews (Johnston et al., 1999). No attempt was made to identify salespeople in specific industries. Therefore, there is ample variability with respect to the goods/services make-up of the products sold and the degree of product customization required by customers. Each followed the same interview protocol.

We used CIT to investigate reacquisition evaluations by asking industrial salespeople to describe in as much detail as possible two incidents: an incident where they successfully attempted to win back a lost customer and an incident where they were unsuccessful. Probing questions followed to have respondents discuss the past working relationships, the reasons customers left and the processes and resources used to facilitate the reacquisition effort. Once the story was captured, we asked the respondents to reflect upon any aspects that helped or hindered the process and if they would have done anything differently. Finally, we asked respondents to compare the differences between winning-back lost customers and acquiring new customers. Following the guidelines of CIT, the number of interviews was not predetermined; instead, it was determined by emerging common themes and repetition of information (Bitner et al., 1990). All critical incident interviews were conducted person-to-person and were transcribed and coded in NVivo 9. Interpretations of the data were discussed, reviewed and agreed upon by the co-authors before results were finalized to report in this study.

\section{Findings}

\section{Sample characteristics}

A total of 54 salespeople were interviewed, generating 108 usable critical incidents for evaluation. In total 76 per cent of respondents were male. On average, respondents were 39 years old and had over 10 years of working experience. In total 55 per cent of the sample had a bachelor's degree with 6 per cent having a master's or higher degree. Further, 43 per cent of the respondents were selling a business service. The official job titles of respondents include: Owner, CEO, Vice President, Managing Director, Head of Corporate Sales, General Manager, Deputy Managing Director, Operations Director, Director of Sales Capability, Executive Director, Business Development, Sales Manager, Account Executive/ Manager, Sales Consultant, Sales Representative, Marketing Representative, Risk Adviser, Team Leader and Sales Promotion Executive.

The framework represents what salespeople do when reacquiring lost customers. Our CIT results show the same five categories of defectors identified by Stauss and Friege's (1999). Practically, all scenarios provide strong evidence that salespeople evaluate the reason(s) for defection and strategically think through the best strategy to facilitate reacquisition. Given the in-depth findings of the qualitative data (and for brevity sake in this paper), we present the following five examples corresponding to five types of defectors to illustrate how each step is adopted by the sales executives.

\section{Example 1: bought away customers}

Step 1: segmenting defectors based on reason for leaving

Many customers can be bought away by competitors by offering a better price. Our study showed many examples. For instance, the Director of a building supplies company recalled 
that he lost a major account mainly because of price competition. He stated:

The customer left purely because of price. I don't think we've let them down in terms of the product, the way we've made it, the delivery, you know [. . . ] I always felt that they were satisfied. And probably in the end, at a certain point, our price may have been a little bit out of kilter, our opposition might have had some cheaper timber [. . .] and all of the sudden they can beat you in the market place, and so I really do think it's more to do with price than anything else.

Step 2: assessing responsibility and reason for loss

The customer defection may be attributed to a competitor (i.e. external source). In a price-driven market place, such situations were likely to reoccur (i.e. stable source) and the competitor might be able to set a threshold to stabilize the price (i.e. uncontrollable/unpreventable). In this case, the attributional analysis showed that the competitor threat was considered to be both eminent and persistent.

Step 3: developing reacquisition activities and capabilities Having lost a major account, a firm tried to win back the customer by waiting and researching the market trends and the customer's continuing needs. The firm did this by:

[. . .] intelligence gathering information which came back to say, well, things weren't quite as good as they appeared to be to start with [. . .] there have been few shortages and maybe they've been let down. We tried to figure out what's really going on and becoming their best friend again [. . .] it started with a phone call.

This is an example of the supplier pursuing active waiting (by gathering information), and better communication to redevelop the relationship and to improve the sale processes.

Step 4: implementing the reacquisition strategy

A sales executive implemented the reacquisition strategy by integrating the elements of procedural and interactional justice and focusing on keeping in contact with the customer. But "cost to serve" was also an issue, as the sales executive stated:

[. . .] maybe in the time when he started to drift away, when he made his decision that he could save money by buying it differently, if we had been a little more attentive and promoted ourselves. But if you burn too much money promoting yourself, promoting [...] we've not got anything really new to offer, so it's just a matter of servicing that job.

\section{Example 2: pulled away customers}

Step 1

Customers can also be lured away because of competitor's better value offerings. For instance, a sales specialist at a telecommunication service provider reported:

The customer was a small business and previously left for a better offer. About 12 months after that we started talking about what we needed to do in order to win them back.

Step 2

Further analysis shows that the cause of customer defection is because of the competitor having a better value proposition. The cause may likely to re-occur because of the competitor's technology capabilities and better ways of providing service. The attributional analysis shows that the customer is value-focused and strategy-driven:

And they had a bunch of technical requirements that needed to be met. The agreement was that if we could meet these requirements they would give their entire business back [...] we talked about it and after 2 or 3 meetings they came back [...] because we started to meet all their needs and did things as they wanted to happen [...]. It wasn't difficult to meet requirements. Not too costly and was relatively simple to win back.
Step 3

Under this situation, the sales executive applied active waiting to re-engage the relationship. The sales firm also developed capability and customized services per the client's needs and requirements.

Step 4

The sales executive implemented the reacquisition strategy by customizing services (i.e. distribution justice), developing capability required by the client (i.e. procedural justice) and with better communications (i.e. interactional justice).

\section{Example 3: the unintentionally pushed away customers}

Step 1

There are situations when the customers are inadvertently mistreated or ignored. Such customers are unintentionally pushed away because of unforeseeable actions of the sales executive or the sales firm. Highlighting the mistreatment of a client, a Sales and Promotions Executive of a media company stated that:

The customer left due to a planned and paid for street activation at a retail store that never took place because of bad communication. This was the start of their summer activations and product sales. The issue arose when the local region did not show up at the event with the activation and promotional staff. The information and booking was never passed onto the local region because our network staff member was away sick [. . ].

Step 2

The customer defection can be attributed to the sales executive and the sales firm. The sales firm took responsibility for the mistake, and wanted to ensure that such incidents would not reoccur. The unfortunate cause of customer defection in situations like this was preventable, and firms had the ability to control such events by improving its due diligence.

Step 3

The firm's win-back activities included apologizing and taking full responsibility for the event, in addition to offering the client a special customized offer:

As you could imagine, the client was less than impressed and stripped all promotional and marketing services with the company. However, due the strong sales/client relationships, we simply emailed, rang and apologized to the client for the mistake and took full responsibility [. . .].

Step 4

The implementation of win back in this scenario took into consideration the distributive and interactional justice elements. The firm relied on its previous strong relationship with the client, which helped in communicating the apology in a way which was well received (human interaction). It also put together a special offer to "make good" with the client and resolve the problem:

To gain back the relationship, we offered them two more on-site activations at a location of their choice at no cost, i.e. a make good.

\section{Example 4: moved-away customers}

Step 1

There are customers that "move away", either physically move away or move the manufacturing/service in-house. The sales process framework for customer re-acquisition in such cases is quite different. For instance, a Sales Representative of a food-manufacturing firm reported: 
The customer felt it was more economical to make this product themselves at a time when they were able to. They had the labor to and they could cut costs [...]. By evaluating the size of the company and the amount of product we had been selling to this customer, we felt like we'd taken quite a big hit. It was definitely worth pursuing them.

Step 2

The cause of defection was the decision by the customer to manufacture its own products. If the customer could expand its own production capabilities and realize the anticipated efficiencies, the customer planned to continue this. The attributional analysis also showed that the customer had a strong capacity for growth.

Step 3

Even though this type of "moved away" customer are quite difficult to reacquire, some may be major accounts (like in the present scenario). The sales executive was actively waiting and communicating with the client for future reacquisition:

We offered them an alternative style, like a USP, they could sell. We couldn't sell the product at a reduced price however. We still haven't been able to win them back but they've left the door open. But there may be times in the future when they may need our services and may look to us as their preferred supplier.

Step 4

This case also highlighted the distributive and interactional justice to resolve the problem. However, as the situation is out of control of the firm or sales executive, all their efforts failed to reacquire the customer. On the positive note, they still left communication channels open, in case the client decided to out-source the production again in the future.

\section{Example 5: intentionally pushed away customers}

Step 1

There were a few examples of companies trying to intentionally push away customers. In one case, a Marketing Manager of a food supplement manufacturer recalled that:

The reason, which also will help explain why he left us, is because we were losing interest in him, and therefore trying to get rid of him in a certain way [. . .]. Because he was such a small account, and very unpredictable with his orders, he was becoming more of a burden for the company, so I remember deciding to reduce the amount of advertising we would send him, and eventually the client just stopped ordering from us.

Step 2

Customer defection in such situation is mainly attributed to the sales organization, as they do not think that the customer is profitable enough in relation to the costs to serve them.

Step 3

Rather than having a win-back strategy in such situations, the selling firm plans a termination strategy. As the sales executive reduced the marketing collateral sent to the client, it eventually left.

Step 4

Although there was no reacquisition strategy, the executive focused on interactive justice and let the client chose to leave on its own accord.

\section{Managerial implications}

Although CRM literature historically emphasizes the best practices and processes to acquire and retain customers, effective sales organizations must also be prepared to deal with lost customers and be able to win them back. To this end, the current study constructs a sales reacquisition process framework by integrating literature on consumer defection, attribution theory, service recovery strategies and justice theory. The findings show that customer reacquisition is an integral part of CRM and that analyzing and resolving customer defection is an important CRM issue. The results provide strong support for the $\mathrm{B} 2 \mathrm{~B}$ sales reacquisition process framework and suggest that sales executives need to manage customer reacquisition with a systematic process.

More specifically, findings from the critical incident interviews highlight the critical nature of accurately diagnosing defections to properly develop and deliver reacquisition efforts. The reacquisition framework illustrates that effective customer reacquisition requires systematic planning, and execution encompassing four important steps: segmenting defectors, assessing responsibility, developing reacquisition activities and implementing strategies. This four-step reacquisition process allows sales firms to identify essential elements and establish protocols and policies to train and mentor salespeople to successfully re-approach and regain valuable lost customers.

Specifically, step one - segmenting defectors - identifies defectors' characteristics and categorizes defection patterns. By demystifying defection patterns, salespeople can better understand customers' reasons for leaving (Step 2). The purpose of Step 2 is to assist salespeople objectively evaluate "who is responsible?", "can it be prevented?" and "will it happen again?" This attribution knowledge can assist salespeople in developing problem-focused solutions, rather than staying focused on the loss itself. More important, by understanding the true cause of defection, salespeople may develop their reacquisition activities (Step 3) more strategically. Step 3 lays out various plausible reacquisition activities for salespeople to consider. By knowing there are combinations of options available, salespeople may be able to effectively re-negotiate and co-create customer-oriented solutions to regain lost business. Finally, rebuilding relationships with lost customers takes more than just customer-oriented solutions to achieve optimal outcomes (i.e. distributed justice). Often, what really matters to customers is how easy or difficult it is to work with the sales firm and/or the sales team again (i.e. procedure justice); and, as important, how they perceive they are treated (i.e. interaction justice).

By integrating a sales reacquisition process framework into the existing CRM, we hope to provide guidance to sales managers to train and motivate salespeople to properly diagnose and win-back lost customers. It is our hope that this framework will be a valuable tool to aid sales executives in reducing inefficiencies in the reacquisition process and increasing sales reacquisition ratios, by effectively assessing and winning-back lost customers.

\section{Limitations and future research}

The qualitative and exploratory nature of this research brings with it accompanying methodological strengths and weaknesses. Although the qualitative CIT allows for the capture of rich information fundamental to theory development, it is less effective at delivering findings that are highly generalizable and prescriptive. So while business practitioners often highly value case-based and qualitative research (Batt, 2012; Johnston et al., 1999), we acknowledge 
its limitations. However, this study can serve to stimulate interest and further research on this topic.

Specifically, it is our hope that this initial study will stimulate further research examining the strategies and practices that salespeople use to reacquire lost customers. With further investigation, generalizable and contextual customer reacquisition frameworks and procedures can be developed that would allow for the effective training of salespeople and facilitate the strategy development activities among salespeople and sales teams. The development of effective customer reacquisition sales processes would assist in demystifying reacquisition efforts by allowing salespeople to more objectively and critically examine opportunities and implement tried and true reacquisition strategies.

Further research examining salesperson resistance, fears and attributions toward reacquiring lost customers is also warranted. Many of the sales executives interviewed for this study expressed having initial reservations about their attempts to reacquire a lost customer. This was particularly true if there was any negativity or dissatisfaction by the customer. This suggests that there may be psychological barriers that a salesperson must overcome when attempting to reacquire defected customers. These barriers are likely to vary with salesperson attributions pertaining to the customer defection (Dixon et al., 2001) and associated justice perceptions.

Literature on B2B exchange relationships and organizational buying behavior can also benefit from the examination of reacquisition activities. For example, several sales executives in our sample emphasized the importance of their ability to leverage past relationships within the lost customer's organization. The existence and strength of positive relations shaped both their reacquisition analysis and efforts. Understanding the types of relationships and the position that both advocates and blockers within the customer buying center play may be critical to a successful win back. In our study, we only examined reacquisition from the perspective of the selling firm. Understanding switching-back behavior from a customer perspective is equally valuable. Thereby, further investigation into the impact of buying center characteristics and dynamics on decisions to return to a former supplier is warranted.

Lastly, we saw signs signifying the importance of competitive and market variables on the feasibility and success of reacquisition efforts. Specifically, the more competitive the market, the more important reacquiring lost customers seems to become. Conversely, sales executives in rapidly growing markets seem less interested in the retention of lost customers as acquiring new customers is relatively easy. However, in our New Zealand-based sample, most executives were in small and highly competitive markets; thus, every potential customer was highly valued. Consequently, another area deserving of future research would be to examine differences in the reacquisition sales process across various market and competitive conditions.

\section{References}

Adams, J.S. (1963), "Toward an understanding of inequity", fournal of Abnormal and Social Psychology, Vol. 67 No. 5, pp. 422-436.
Batt, P.J. (2012), "Measures and measurement: process and practise", Industrial Marketing Management, Vol. 41 No. 3, pp. 379-384.

Bitner, M.J., Booms, B.H. and Tetreault, M.S. (1990), "The service encounter: diagnosing favorable and unfavorable incidents", fournal of Marketing, Vol. 54 No. 1, pp. 71-84.

Dalela, V. (2009), "A study of relationship repair in a businessto-business context", Published dissertation, The University of Alabama, Tuscaloosa, AL.

DeCarlo, T.E., Agarwal, S. and Vyas, S.B. (2007), "Performance expectations of salespeople: the role of past performance and causal attributions in independent and interdependent cultures", Fournal of Personal Selling and Sales Management, Vol. 27 No. 2, pp. 133-147.

Dixon, A.L., Spiro, R.L. and Jamil, M. (2001), "Successful and unsuccessful sales calls: measuring salesperson attributions and behavioral intentions", The fournal of Marketing, Vol. 65 No. 3, pp. 64-78.

Dixon, A.L., Spiro, R.L. and Schertzer, S.M. (2005), "Bouncing back: how salesperson optimism and selfefficacy influence attributions and behaviors following failure", Fournal of Personal Selling and Sales Management, Vol. 25 No. 4, pp. 361-369.

Dixon, A.L., Spiro, R.L. and Tanner, J. (2012), "Transforming selling: why it is time to think differently about sales research", The Fournal of Personal Selling \& Sales Management, Vol. 32 No. 1, p. 9.

Dubinsky, A.J. (1980/1981), "A factor analytic study of the personal selling process", fournal of Personal Selling $\mathcal{E}$ Sales Management, Vol. 1 No. 1, pp. 26-33.

Dwyer, F.R., Schurr, P.H. and Oh, S. (1987), "Developing buyer-seller relationships", fournal of Marketing, Vol. 51, pp. 11-27.

Gilbert, D.T. (1995), "Attribution and interpersonal perception", in Tesser, A. (Ed.), Advanced Social Psychology, McGraw-Hill, New York, NY, pp. 99-147.

Gonzalez, G.R., Hoffman, K.D. and Ingram, T.N. (2005), "Improving relationship selling through failure analysis and recovery efforts: a framework and call to action", fournal of Personal Selling $\mathcal{E}$ Sales Management, Vol. 25 No. 1, pp. 57-65.

Gonzalez, G.R., Hoffman, K.D., Ingram, T.N. and LaForge, R.W. (2010), "Sales organization recovery management and relationship selling: a conceptual model and empirical test", Fournal of Personal Selling and Sale Management, Vol. 30 No. 3, pp. 223-223.

Greenberg, J. (1990), "Organizational justice: yesterday, today, and tomorrow”, fournal of Management, Vol. 16 No. 2, pp. 399-432.

Hoffman, K.D. and Kelley, S.W. (1996), "Guidelines for developing retail recovery strategies", in Wilson, E.J. and Hair, J.F. Jr (Eds), Developments in Marketing Science, Academy of Marketing Science, Phoenix, AZ, p. 123.

Hoffman, K.D. and Kelley, S.W. (2000), "Perceived justice needs and recovery evaluation: a contingency approach", European fournal of Marketing, Vol. 34 Nos 3/4, pp. 418-433.

Homburg, C., Hoyer, W.D. and Stock, R.M. (2007), "How to get lost customers back?", Fournal of the Academy of Marketing Science, Vol. 35 No. 4, pp. 461-474. 
Johnson, J.T., Barksdale, H.C. Jr and Boles, J.S. (2001), "The strategic role of the salesperson in reducing customer defection in business relationships", The fournal of Personal Selling and Sales Management, Vol. 21 No. 2, pp. 123-134.

Johnston, T.C. and Hewa, M.A. (1997), "Fixing service failures", Industrial Marketing Management, Vol. 26, pp. 67-473.

Johnston, W.J., Leach, M.P. and Liu, A.H. (1999), "Theory testing using case studies in business-to-business research", Industrial Marketing Management, Vol. 28 No. 3, pp. 201-213.

Keaveney, S.M. (1995), "Professional services marketing: strategy and tactics", fournal of Academy of Marketing Science, Vol. 23 No. 3, p. 220.

Liu, A.H., Leach, M.P. and Bernhardt, K. (2005), "Examining customer value perceptions of organizational buyers when sourcing from multiple vendors", fournal of Business Research, Vol. 58 No. 5, pp. 559-568.

Liu, A.H., Wang, S. and Leach, M.P. (2012), "Considering culture to win back customers: comparing Chinese and American consumers", Fournal of Customer Satisfaction/ Dissatisfaction and Complaining Behavior, Vol. 25, pp. 149-158.

Mars, G. and Nicod, M. (1984), The World of Waiters, Allen \& Unwin, London.

Marshall, G.W., Moncrief, W.C. and Lassk, F.G. (1999), "The current state of sales force activities", Industrial Marketing, Management, Vol. 28 No. 1, pp. 87-98.

Moncrief, W.C. and Marshall, G.W. (2005), "The evolution of seven steps of selling", Industrial Marketing Management, Vol. 34 No. 1, pp. 13-21.

Page, M., Pitt, L. and Berthon, P. (1996), "Analyzing and reducing customer defections", Long Range Planning, Vol. 29 No. 6, pp. 821-834.

Palmatier, R.W., Scheer, L.K. and Steenkamp, J.E.M. (2007), "Customer loyalty to whom? Managing the risks of salesperson-owned loyalty", fournal of Marketing Research, Vol. 44, pp. 185-199.

Parasuraman, A., Zeithaml, V.A. and Berry, L.L. (1988), "SERVQUAL", fournal of Retailing, Vol. 64 No. 1, pp. $12-40$

Plouffe, C.R., Nelson, Y.H. and Beuk, F. (2013), "Testing an enhanced process-based view of the sales process", fournal of Personal Selling and Sales Management, Vol. 33 No. 2, pp. 141-164.

Reichheld, F.F. (1993), "Loyalty-based management", Harvard Business Review, Vol. 71 No. 2, pp. 64-73.

Saxe, R. and Weitz, B.A. (1982), "The SOCO scale: a measure of the customer orientation of salespeople", Fournal of Marketing Research, Vol. 19 No. 3, pp. 343-351.
Stauss, B. and Friege, C. (1999), "Regaining service customers", fournal of Service Research, Vol. 1 No. 14, pp. 347-361.

Swanson, S. and Kelley, S. (2001), "Service recovery attributions and word-of-mouth intentions", European Fournal of Marketing, Vol. 25 Nos 1/2, pp. 194-221.

Tax, S.S., Brown, S.W. and Chandrashekaran, M. (1998), "Customer evaluations of service complaint experiences: implications for relationship marketing", fournal of Marketing, Vol. 62, pp. 60-76.

Thomas, J.S., Blatiberg, R.C. and Fox, E.J. (2004), "Recapturing lost customers", fournal of Marketing Research, Vol. 41 No. 1, pp. 31-45.

Tokman, M.D., Davis, L.M. and Lemon, K.N. (2007), "The WOW factor: creating value through win-back offers to reacquire lost customers", fournal of Retailing, Vol. 83 No. 1, pp. 47-64.

Weiner, B. (1980), Human Motivation, Holt, Rinehart and Winston, New York, NY.

\section{About the authors}

Annie Liu is Associate Professor of Marketing at Texas State University. Her areas of expertise and research mainly focus on B2B networks, including B2B marketing and sales, customer retention and reacquisition, international marketing and cross cultural networks. She has published in Industrial Marketing Management, Fournal of Business Research, Fournal of Marketing Theory $\mathcal{E}$ Practice, Fournal of Business $\mathcal{E}$ Industrial Marketing, Fournal of Business-to-Business Marketing, and Fournal of Personal Selling $\mathcal{E}$ Sales Management, among others. Dr Liu received her PhD from Georgia State University. Annie Liu is the corresponding author and can be contacted at:drahliu@gmail.com

Mark Leach is Professor and Department Chair for Marketing and Business Law at Loyola Marymount University in Los Angeles. His areas of expertise and research include sales training and development, industrial marketing strategy, CRM and sales force automation. He has published in Industrial Marketing Management, fournal of Business Research, Fournal of Business $\mathcal{E}$ Industrial Marketing, Fournal of Business-to-Business Marketing, and Fournal of Personal Selling $\mathcal{E}$ Sales Management, among others. Dr Leach received his $\mathrm{PhD}$ from Georgia State University.

Richa Chugh is a doctoral candidate at Victoria Business School in Wellington, New Zealand. Her research interests include exporting, channel relationships, customer reacquisition and relationship marketing. 